\title{
Chromenone Derivatives as Monoamine Oxidase Inhibitors from Marine-Derived MAR4 Clade Streptomyces sp. CNQ-031
}

\author{
Jong Min Oh', Chaeyoung Lee ${ }^{2}$, Sang-Jip Nam ${ }^{3}$, and Hoon Kim ${ }^{1 *}$ \\ 'Department of Pharmacy, and Research Institute of Life Pharmaceutical Sciences, Sunchon National University, \\ Suncheon 57922, Republic of Korea \\ ${ }^{2}$ Graduate School of Industrial Pharmaceutical Sciences, Ewha Womans University, Seoul 03760, Republic of Korea \\ ${ }^{3}$ Department of Chemistry and Nanoscience, Ewha Womans University, Seoul 03760, Republic of Korea \\ Three compounds were isolated from marine-derived Streptomyces sp. CNQ-031, and their \\ inhibitory activities against monoamine oxidases (MAOs), acetylcholinesterase (AChE), \\ butyrylcholinesterase (BChE), and $\beta$-secretase (BACE-1) were evaluated. Compound 1 (5,7- \\ dihydroxy-2-isopropyl-4H-chromen-4-one) was a potent and selective inhibitor of MAO-A, with a \\ $50 \%$ inhibitory concentration (IC $\left.\mathrm{C}_{50}\right)$ of $2.70 \mu \mathrm{M}$ and a selectivity index (SI) of 10.0 versus MAO-B. \\ Compound 2 [5,7-dihydroxy-2-(1-methylpropyl)-4H-chromen-4-one] was a potent and low-selective

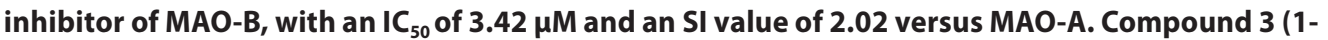 \\ methoxyphenazine) did not inhibit MAO-A or MAO-B. All three compounds showed little inhibitory \\ activity against $A C h E, B C h E$, and $B A C E-1$. The $K_{i}$ value of compound 1 for $M A O-A$ was $0.94 \pm 0.28 \mu M$, \\ and the $K_{i}$ values of compound 2 for MAO-A and MAO-B were $3.57 \pm 0.60$ and $1.89 \pm 0.014 \mu \mathrm{M}$, \\ respectively, with competitive inhibition. The 1-methylpropyl group in compound 2 increased the \\ MAO-B inhibitory activity compared with the isopropyl group in compound 1. Inhibition of MAO-A \\ and MAO-B by compounds 1 and 2 was recovered by dialysis experiments. These results suggest that \\ compounds 1 and 2 are reversible, competitive inhibitors of MAOs and can be considered potential \\ therapies for neurological disorders such as depression and Alzheimer's disease.
}

Keywords: Monoamine oxidases, chromenone derivatives, Streptomyces sp. CNQ-031, reversible competitive inhibitors

Received: May 4, 2021 Accepted: May 27, 2021

First published online: May 31, 2021

*Corresponding author Phone: +82-61-750-3751 Fax: +82-61-750-3708 E-mail: hoon@sunchon.ac.kr

pISSN 1017-7825 elSSN 1738-8872

Copyright(C) 2021 by The Korean Society for Microbiology and Biotechnology

\section{Introduction}

Monoamine oxidase (MAO; E.C. 1.4.3.4) is bound in the mitochondrial outer membrane and catalyzes the oxidative deamination of various primary, secondary, and tertiary amines, including monoamine neurotransmitter amines and therapeutic drugs [1]. MAO plays important roles in the pathways of catecholamine and 5hydroxytryptamine inactivation. Inhibition of MAO offers antidepressant activities and behavioral benefits in the brain, so MAO is a major pharmaceutical target for drug design [1,2]. MAO exists in two isoforms: MAO-A and MAO-B. Selective inhibitors of MAO-A are associated with antidepressive activity, whereas selective inhibitors of MAO-B have been used to treat Alzheimer's disease (AD) and Parkinson's disease (PD) [3]. MAO-A inhibitors preferentially remove serotonin, dopamine, and norepinephrine [4]. MAO-B is related to the inhibition of $\beta$ amyloid plaque formation associated with $\mathrm{AD}$ [5]. Thus, various selective MAO-B inhibitors are being actively studied $[6,7]$ and have been reviewed recently $[8,9]$. Furthermore, serious side effects of MAO inhibitors have not yet been reported [3].

Conversely, acetylcholinesterase (AChE; E.C. 3.1.1.7) has therapeutic efficacy in AD by improving cholinergic transmission, which increases synaptic acetylcholine (ACh) levels in the cerebral cortex of patients with AD [10]. Several studies have demonstrated the clinical benefits of sustained cholinesterase (ChE) inhibition by rivastigmine in $\mathrm{AD}$ and PD. Rivastigmine has inhibitory activity against both AChE and butyrylcholinesterase (BChE; E.C. 3.1.1.8), whereas donepezil and galantamine selectively inhibit AChE [11]. Recently, therapeutic strategies have been devised using multitarget inhibitors that block both MAO and ChE; these studies demonstrated that MAO and AChE inhibitors can improve cognitive function and relieve AD symptoms by increasing the levels of monoamines and choline esters [12-14]. In addition, $\beta$-secretase (BACE-1) inhibitors have been studied to treat $\mathrm{AD}$ and $\mathrm{PD}$ because of their ability to inhibit $\beta$-amyloid accumulation [15].

Natural MAO inhibitors have been isolated and investigated from microbial sources, including aplysinopsins from Aplysinopsis sp. [16], piloquinones from Streptomyces sp. [17], anithiactins from Streptomyces sp. [18], and 5- 
hydroxy-2-methyl-chroman-4-one (HMC) from the endogenous lichen fungus Daldinia fissa [19]. Marine natural MAO inhibitors in particular have recently been reviewed [20]. In this study, we isolated three compounds from a marine-derived Streptomyces sp., identified their structures and investigated their MAO inhibitory activities, as well as the AChE, BChE, and BACE-1 inhibitory activities, for their possible multitarget inhibitions.

\section{Materials and Methods \\ Structural Analysis}

Optical rotations were acquired using a Kruss Optronic P-8000 polarimeter with a 5-cm cell. The ultraviolet (UV) spectra were measured with a V-730 UV-visible spectrophotometer (Jasco, USA) using a path length of $1 \mathrm{~cm}$. The infrared spectra were recorded on a Varian Scimitar Series in $\mathrm{CHCl}_{3}$. The nuclear magnetic resonance (NMR) spectra were acquired at $300 \mathrm{MHz}$ for ${ }^{1} \mathrm{H}$ in $\mathrm{CD}_{3} \mathrm{OD}$ and DMSO- $d_{6}$ using a solvent signal as an internal reference $\left(\delta_{\mathrm{H}} 3.31\right.$ and $\delta_{\mathrm{H}} 2.50$ for the respective solvents). Mass data were obtained on an Agilent Technologies 6120 quadrupole. Electrospray ionization mass spectroscopy (ESIMS) data were collected using an Agilent Technologies 6120 quadrupole mass spectrometer (Santa Clara, CA) coupled with an Agilent Technologies 1260 series HPLC with a reversed-phase column (Phenomenex Luna C-18(2) $(100 \AA$, $50 \mathrm{~mm} \times 4.6 \mathrm{~mm}, 5 \mu \mathrm{m})$ at a flow rate of $1.0 \mathrm{ml} / \mathrm{min}$. The fractions were purified by a Waters 616 quaternary HPLC pump and a Waters 996 photodiode array detector using a Phenomenex Luna C-18(2) $(250 \mathrm{~mm} \times 10 \mathrm{~mm}, 5 \mu \mathrm{m})$ reversed HPLC column. HRMS analysis was conducted with a JEOL JMS-AX505WA mass spectrometer.

\section{Bacterial Culture and Isolation of Compounds}

The marine-derived actinomycetes strain CNQ-031 was isolated from sediment sampled off the coast of California. It was identified as belonging to the Streptomyces sp. MAR4 clade on the basis of 16S rRNA gene sequence analysis. Strain CNQ-031 was cultured in $40 \mathrm{~L}$ of a 2.5 -L ultra-yield flask containing $1 \mathrm{~L}$ of SYP SW medium ( $10 \mathrm{~g} / \mathrm{l}$ of soluble starch, $2 \mathrm{~g} / \mathrm{l}$ of yeast, $4 \mathrm{~g} / \mathrm{l}$ of peptone, $10 \mathrm{~g} / \mathrm{l}$ of $\mathrm{CaCO}_{3}, 20 \mathrm{~g} / \mathrm{l}$ of $\mathrm{KBr}, 8 \mathrm{~g} / \mathrm{l}$ of $\mathrm{Fe}_{2}\left(\mathrm{SO}_{4}\right)_{3} \times$ $4\left(\mathrm{H}_{2} \mathrm{O}\right)$ dissolved in $750 \mathrm{ml}$ natural seawater and $250 \mathrm{ml}$ of distilled water) at $25^{\circ} \mathrm{C}$ with shaking at $150 \mathrm{rpm}$ for 7 days. The culture medium was extracted with EtOAc (40 L overall), and the EtOAc-soluble fraction was concentrated in vacuo to yield $5.84 \mathrm{~g}$ of crude extract. The entire crude extract was fractionated by C-18 open column chromatography with a step gradient from $20 \%$ to $100 \% \mathrm{MeOH}$ in distilled water to obtain nine fractions. The third fraction was subjected to reversed-phase HPLC with $39 \%$ aqueous acetonitrile (Phenomenex Luna C$18(2)(100 \AA, 250 \mathrm{~mm} \times 100 \mathrm{~mm}, 2.0 \mathrm{ml} / \mathrm{min}, 5 \mu \mathrm{m})$ to obtain compound $\mathbf{1}(19.8 \mathrm{mg})$. The fourth fraction was chromatographed and eluted with $50 \%$ acetonitrile to isolate compound $3(6.0 \mathrm{mg})$, and the fifth fraction was purified with $47 \%$ acetonitrile to provide compound 2 (11.4 mg).

\section{Chemicals and Enzyme Assays}

Recombinant human MAO-A and human MAO-B, AChE from Electrophorus electricus, BChE from equine serum, the BACE-1 Activity Detection Kit, kynuramine, benzylamine, 5,5'-dithiobis(2-nitrobenzoic acid) (DTNB), acetylthiocholine iodide (ATCI), S-butyrylthiocholine iodide (BTCI), and reference reversible inhibitors (toloxatone, lazabemide, donepezil, and quercetin as inhibitors of MAO-A, MAO-B, AChE, BChE, and BACE-1, respectively) were purchased from Sigma-Aldrich (USA) [21]. The reference irreversible inhibitors (clorgyline and pargyline, inhibitors of MAO-A and MAO-B, respectively) were obtained from Bioassay Systems (USA) [22]. All other chemicals were of reagent grade.

$\mathrm{MAO}-\mathrm{A}$ and MAO-B inhibitory activities were determined using a continuous spectrophotometric method as described previously $[23,24]$. The $\mathrm{K}_{\mathrm{m}}$ values of MAO-A for kynuramine and of MAO-B for benzylamine were 0.024 and $0.14 \mathrm{mM}$, respectively. The concentrations of kynuramine $(0.06 \mathrm{mM})$ and benzylamine $(0.3 \mathrm{mM})$ used were 1.5 and 1.8 times the respective $\mathrm{K}_{\mathrm{m}}$ values. AChE activities were assayed as described by Ellman et al. [25], with slight modification $[26,27]$. The inhibitory activities of $\mathrm{AChE}$ and $\mathrm{BChE}$ were measured after the enzyme was preincubated with inhibitors for $15 \mathrm{~min}$ and before adding DTNB and the substrate (ATCI and BTCI, respectively). Reactions were performed using approximately $0.2 \mathrm{U} / \mathrm{ml}$ of $\mathrm{AChE}$ and $\mathrm{BChE}$ in the presence of $0.5 \mathrm{mM}$ DTNB and $0.5 \mathrm{mM}$ substrate (ATCI and BChE) in $0.5-\mathrm{ml}$ reaction mixtures; reactions were continuously monitored for $10 \mathrm{~min}$ at $412 \mathrm{~nm}$. Reaction rates were expressed as changes in absorbance per minute [28]. BACE1 assays were performed using the BACE-1 kit at 320 and $405 \mathrm{~nm}$ for excitation and emission wavelengths, respectively, and a fluorescence spectrometer (FS-2, Scinco, Korea) after reaction for $2 \mathrm{~h}$ at $37^{\circ} \mathrm{C}$ with 7methoxycoumarin-4-acetyl-[Asn670,Leu671]-amyloid $\beta / A 4$ protein fragment 667-676-(2,4-dinitrophenyl)LysArg-Arg amide trifluoroacetate as a substrate [29].

\section{Analysis of Inhibitory Activities of the Isolated Compounds}

Inhibition of MAOs, AChE, BChE, and BACE-1 by the three compounds was investigated at a concentration of $10 \mu \mathrm{M}$, and then $\mathrm{IC}_{50}$ values of the compounds and the reference inhibitors were determined. Kinetic parameters, inhibition types, and kinetic of inhibition $\left(\mathrm{K}_{\mathrm{i}}\right)$ values of potent MAO-A and MAO-B inhibitors (i.e., compound $\mathbf{1}$ for MAO-A; compound 2 for MAO-A and MAO-B) were determined, as previously described [26]. The $\mathrm{K}_{\mathrm{i}}$ values were measured at five different substrate concentrations for each MAO isoform $(0.0075,0.015,0.03,0.06$, and 0.12 $\mathrm{mM}$ for MAO-A; $0.03,0.06,0.15,0.3$, and $0.6 \mathrm{mM}$ for MAO-B) and in the absence or presence of each inhibitor at concentrations of approximately $0.5,1.0$, and 2.0 times their $\mathrm{IC}_{50}$ values [21]. Inhibitory patterns and $\mathrm{K}_{\mathrm{i}}$ values were determined using Lineweaver-Burk plots and secondary plots of their slopes. 
Reversibility Tests of Compounds 1 and 2

The reversibilities of MAO inhibition by compounds $\mathbf{1}$ and $\mathbf{2}$ and by the reference compounds (toloxatone and clorgyline for MAO-A; lazabemide and pargyline for $\mathrm{MAO}-\mathrm{B}$ ) at twice the $\mathrm{IC}_{50}$ concentrations were investigated by dialysis as previously described [22]. After the compounds or reference inhibitors were preincubated with MAOs for $30 \mathrm{~min}$, residual activities for undialyzed and dialyzed samples were measured. The relative values for undialyzed $\left(\mathrm{A}_{U}\right)$ and dialyzed $\left(\mathrm{A}_{\mathrm{D}}\right)$ activities were then calculated, and the reversibilities were determined by comparing the $A_{U}$ and $A_{D}$ values of the inhibitors with those of the references.

\section{Results and Discussion}

Isolation and Identification of the Compounds

According to the procedure, three compounds were isolated, and their properties were as follows: compound 1 was a light-brown powder, LR-MS $[\mathrm{M}+\mathrm{H}]^{+} \mathrm{m} / z$ 221.1; compound 2 was a yellowish amorphous powder, LR-MS $[\mathrm{M}+\mathrm{H}]^{+} \mathrm{m} / z$ 235.2; and compound 3 was a yellow solid, LR-MS $[\mathrm{M}+\mathrm{H}]^{+} \mathrm{m} / z$ 211.1. The ${ }^{1} \mathrm{H}$ NMR spectrum of compound 1 displayed a pair of meta-coupled aromatic protons $\left[\delta_{\mathrm{H}} 6.33(1 \mathrm{H}, \mathrm{d}, J=2.2 \mathrm{~Hz}, \mathrm{H}-8)\right.$ and $6.19(1 \mathrm{H}, \mathrm{d}, J$ $=2.2 \mathrm{~Hz}, \mathrm{H}-6)]$, an olefinic proton $\left[\delta_{\mathrm{H}} 6.05(1 \mathrm{H}, \mathrm{s}, \mathrm{H}-3)\right]$, and an upfielded proton $\left[\delta_{\mathrm{H}} 2.88(1 \mathrm{H}\right.$, sext, $J=7.2 \mathrm{~Hz}, \mathrm{H}-$ $\left.\left.1^{\prime}\right)\right]$. The ${ }^{1} \mathrm{H}$ NMR spectrum also displayed the two methyl singlets $\left[\delta_{\mathrm{H}} 1.32\left(3 \mathrm{H}, \mathrm{s}, \mathrm{H}-2^{\prime}\right)\right.$ and $\left.1.30\left(3 \mathrm{H}, \mathrm{s}, \mathrm{H}-3^{\prime}\right)\right]$. When the NMR data were compared with previous data, compound 1 was identified as 5,7-dihydroxy-2isopropyl-4H-chromen-4-one [30]. The ${ }^{1} \mathrm{H}$ NMR spectrum of compound 2 revealed a pair of meta-coupled aromatic protons $\left[\delta_{\mathrm{H}} 6.33(1 \mathrm{H}, \mathrm{d}, J=2.2 \mathrm{~Hz}, \mathrm{H}-8)\right.$ and $\left.6.20(1 \mathrm{H}, \mathrm{d}, J=2.2 \mathrm{~Hz}, \mathrm{H}-6)\right]$, one olefinic proton $\left[\delta_{\mathrm{H}} 6.05\right.$ $(1 \mathrm{H}, \mathrm{s}, \mathrm{H}-3)]$, and three upfielded protons $\left[\delta_{\mathrm{H}} 2.64\left(1 \mathrm{H}\right.\right.$, sext, $\left.J=7.2 \mathrm{~Hz}, \mathrm{H}-1^{\prime}\right), 1.75\left(1 \mathrm{H}, \mathrm{m}, \mathrm{H}-3^{\prime} \mathrm{a}\right), 1.64(1 \mathrm{H}, \mathrm{m}, \mathrm{H}-$ $\left.\left.3^{\prime} \mathrm{b}\right)\right]$. The ${ }^{1} \mathrm{H}$ NMR spectrum also displayed the two methyl singlets $\left[\delta_{\mathrm{H}} 1.29\left(3 \mathrm{H}, \mathrm{s}, \mathrm{H}-2^{\prime}\right)\right.$ and $0.94(3 \mathrm{H}, \mathrm{t}, J=8.0$ $\left.\left.\mathrm{Hz}, \mathrm{H}-4^{\prime}\right)\right]$. The ${ }^{13} \mathrm{C}$ NMR data of compound 2 showed 13 carbon signals, including two methyl carbons $\left[\delta_{\mathrm{C}} 11.9\right.$ $\left.\left(\mathrm{C}-4^{\prime}\right), 18.2\left(\mathrm{C}-2^{\prime}\right)\right]$, a methylene $\left[\delta_{\mathrm{C}} 28.6\left(\mathrm{C}-3^{\prime}\right)\right]$, an allylic methine $\left[\delta_{\mathrm{C}} 41.7\left(\mathrm{C}-1^{\prime}\right)\right]$, and six aromatic carbons $\left[\delta_{\mathrm{C}}\right.$ 94.8 (C-8), 100.1 (C-6), 107.6 (C-3), 159.9 (C-1a), 163.3 (C-5), and 166.1 (C-7)], together with an olefinic carbon $\left[\delta_{\mathrm{C}} 105.4(\mathrm{C}-4 \mathrm{a})\right]$, an oxygenated olefinic carbon $\left[\delta_{\mathrm{C}} 175.8(\mathrm{C}-2)\right]$, and a conjugated carbonyl group $\left[\delta_{\mathrm{C}} 184.1(\mathrm{C}-\right.$ 4)]. A comparison of the ${ }^{1} \mathrm{H}$ and ${ }^{13} \mathrm{C}$ NMR data to the previous data identified compound 2 as 5,7-dihydroxy-2-(1methylpropyl)-4H-chromen-4-one [30]. The ${ }^{1} \mathrm{H}$ NMR data of compound 3 showed seven aromatic protons in a 1,2,3-trisubstituted aromatic spin system $\left[\delta_{\mathrm{H}} 7.53(1 \mathrm{H}, \mathrm{dd}, J=7.47,2.49 \mathrm{~Hz}, \mathrm{H}-9), 7.42(1 \mathrm{H}\right.$, dd, $J=7.47,2.49 \mathrm{~Hz}$, $\mathrm{H}-6), 7.16(1 \mathrm{H}, \mathrm{m}, \mathrm{H}-7), 7.14(1 \mathrm{H}, \mathrm{m}, \mathrm{H}-8)]$ and a $1,2,3,4$-tetrasubstituted aromatic $\left[\delta_{\mathrm{H}} 7.06(1 \mathrm{H}, \mathrm{d}, J=8.22 \mathrm{~Hz}, \mathrm{H}-\right.$ 4), $7.00(1 \mathrm{H}, \mathrm{dd}, J=8.81,1.49 \mathrm{~Hz}, \mathrm{H}-3), 6.48(1 \mathrm{H}, \mathrm{d}, J=7.47 \mathrm{~Hz}, \mathrm{H}-2)]$, respectively. These aromatic protons revealed the presence of a phenazine moiety. The ${ }^{1} \mathrm{H}$ NMR data also displayed a methoxy proton $\left[\delta_{\mathrm{H}} 3.77(3 \mathrm{H}, \mathrm{s}, \mathrm{H}\right.$ 11)]. Compound 3 was identified as 1-methoxyphenazine according to a comparison of the ${ }^{1} \mathrm{H}$ and ${ }^{13} \mathrm{C}$ NMR data with previously reported data [31]. The structures of compounds 1, 2, and $\mathbf{3}$ are shown in Fig. 1.<smiles>CC(C)c1cc(=O)c2c(O)cc(O)cc2o1</smiles>

1<smiles>CCC(C)c1cc(=O)c2c(O)cc(O)cc2o1</smiles>

2<smiles>COc1cccc2nc3ccccc3nc12</smiles>

3

Fig. 1. Structures of compounds 1, 2, and 3, which were isolated from Streptomyces sp. CNQ-031.

Inhibitory Activities of the Compounds

The three isolated compounds were assayed for inhibitory activity against MAOs, ChEs, and BACE- 1 . Compounds 1 and 2 showed residual activities of $25.4 \%$ and $37.8 \%$, respectively, for MAO-A, and showed activities of $71.5 \%$ and $34.4 \%$, respectively, for MAO-B at $10 \mu \mathrm{M}$ (Table 1). Compound 3 showed little inhibitory

Table 1. Inhibition of MAO-A, MAO-B, AChE, BChE, and BACE-1 by the compounds isolated from Streptomyces sp. CNQ-031 ${ }^{\mathrm{a}}$.

\begin{tabular}{|c|c|c|c|c|c|c|c|c|c|c|c|}
\hline \multirow{2}{*}{ Compounds } & \multicolumn{4}{|c|}{ Residual activity at $10 \mu \mathrm{M}(\%)$} & \multirow[b]{2}{*}{ BACE-1 } & \multicolumn{5}{|c|}{$\mathrm{IC}_{50}(\mu \mathrm{M})$} & \multirow{2}{*}{$\mathrm{SI}^{\mathrm{b}}$} \\
\hline & MAO-A & MAO-B & AChE & BChE & & MAO-A & MAO-B & AChE & BChE & BACE-1 & \\
\hline 1 & $25.4 \pm 2.24$ & $71.5 \pm 5.45$ & $70.5 \pm 6.31$ & $80.7 \pm 3.46$ & $85.8 \pm 0.28$ & $2.70 \pm 0.034$ & $27.0 \pm 2.78$ & $31.7 \pm 2.39$ & - & - & 10.0 \\
\hline 2 & $37.8 \pm 0.82$ & $34.4 \pm 7.95$ & $88.3 \pm 2.54$ & $96.4 \pm 4.27$ & $98.3 \pm 0.27$ & $6.92 \pm 0.067$ & $3.42 \pm 1.47$ & - & - & - & 2.02 \\
\hline 3 & $93.6 \pm 4.11$ & $96.9 \pm 2.65$ & $83.0 \pm 8.24$ & $97.0 \pm 2.72$ & $79.9 \pm 0.73$ & - & - & - & - & - & \\
\hline Toloxatone & & & & & & $1.08 \pm 0.025$ & - & - & - & - & \\
\hline Lazabemide & & & & & & - & $0.11 \pm 0.016$ & - & - & - & \\
\hline Clorgyline & & & & & & $0.0070 \pm 0.0007$ & - & - & - & - & \\
\hline Pargyline & & & & & & - & $0.14 \pm 0.0059$ & - & - & - & \\
\hline Donepezil & & & & & & - & - & $0.0095 \pm 0.0019$ & $0.18 \pm 0.0038$ & - & \\
\hline Quercetin & & & & & & - & - & - & - & $13.4 \pm 0.035$ & \\
\hline
\end{tabular}

Results are the means \pm SD of duplicate experiments.

${ }^{\mathrm{b}} \mathrm{SI}$ values were given as the ratio of high $\mathrm{IC}_{50} /$ low $\mathrm{IC}_{50}$ for $\mathrm{MAO}$ inhibition. 
A Undialyzed

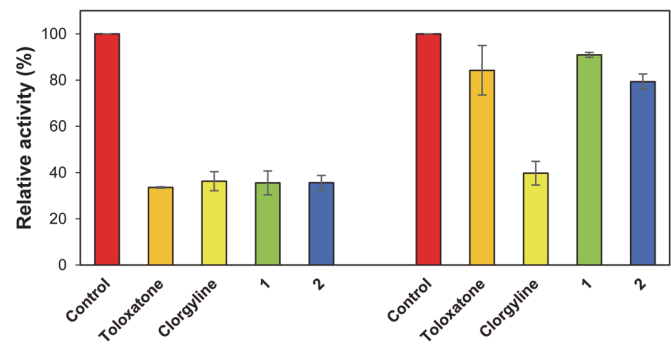

B Undialyzed

Dialyzed

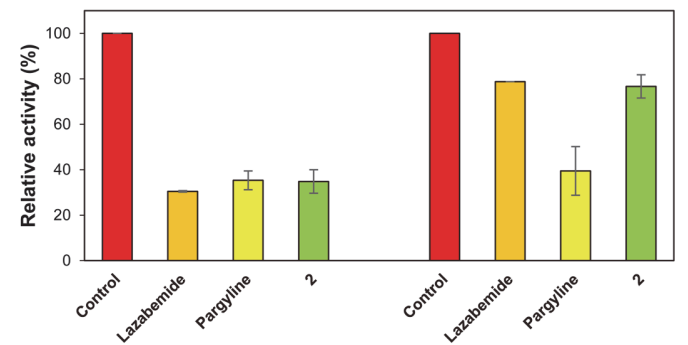

Fig. 2. Recovery of monoamine oxidase (MAO)-A inhibition by compounds 1 and 2 (A) and of MAO-B inhibition by compound 2 (B) after dialysis. To study MAO-A inhibition, toloxatone $(2.16 \mu \mathrm{M})$ and clorgyline $(0.014 \mu \mathrm{M})$ were used as the reference reversible and irreversible inhibitors, respectively, for compounds $\mathbf{1}(5.40 \mu \mathrm{M})$ and 2 $(13.8 \mu \mathrm{M})$. To study MAO-B inhibition, lazabemide $(2.20 \mu \mathrm{M})$ and pargyline $(0.28 \mu \mathrm{M})$ were used as the reference reversible and irreversible MAO-B inhibitors, respectively, for compound $2(6.84 \mu \mathrm{M})$. Results are the averages of experiments performed in duplicate.
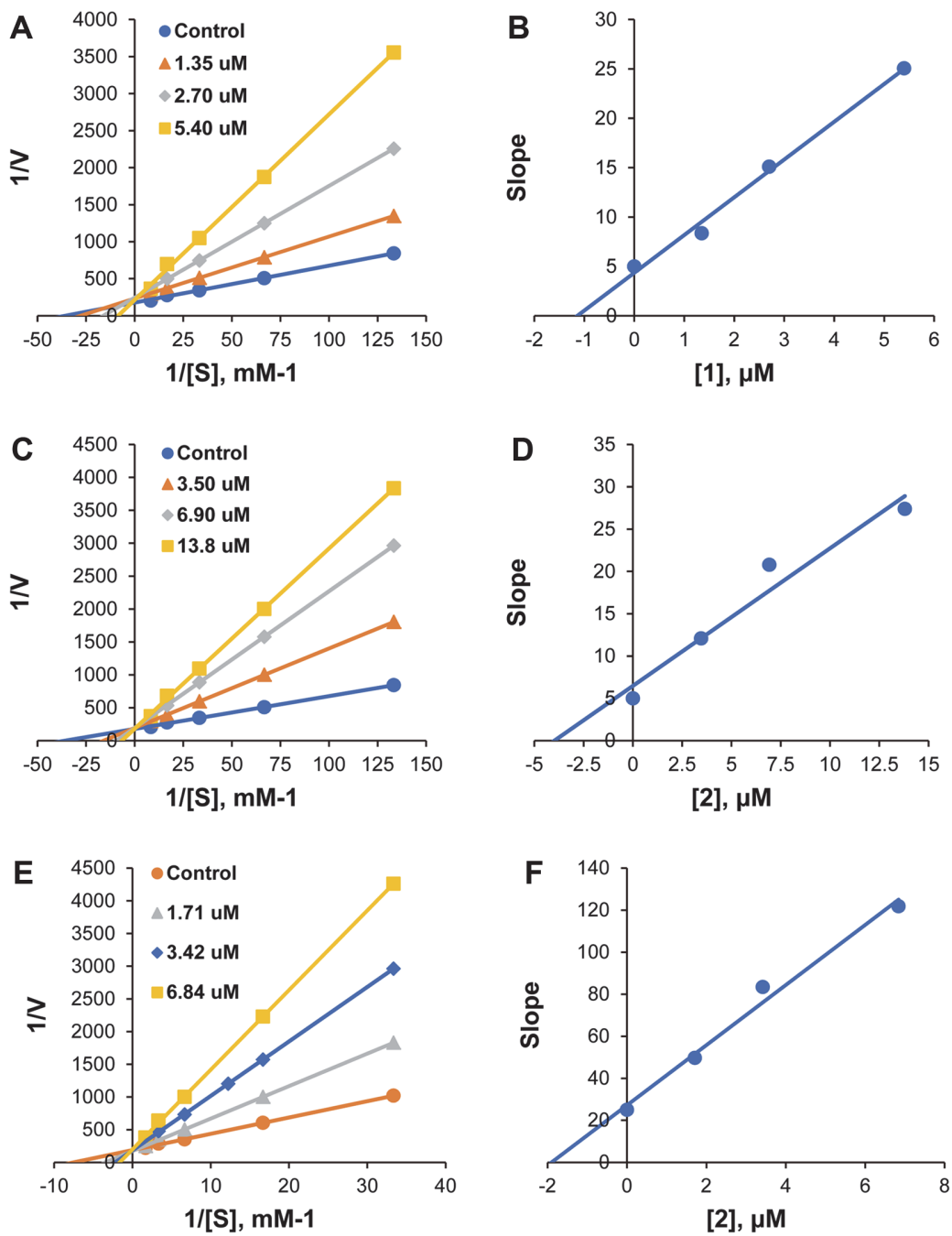

Fig. 3. Lineweaver-Burk plots of monoamine oxidase (MAO)-A inhibition by compound 1 (A) and of MAO$\mathrm{A}$ and MAO-B inhibition by compound 2 ( $\mathrm{C}$ and $\mathrm{E}$ for respective $\mathrm{MOA}$ isoforms) as well as their respective secondary plots, as slopes of Lineweaver-Burk plots vs. inhibitor concentrations ( $B, D$, and F). Substrate MAO$\mathrm{A}$ and MAO-B concentrations ranged from 0.0075 to 0.12 and from 0.03 to $0.6 \mathrm{mM}$, respectively. Experiments were carried out at three inhibitor concentrations: $\sim 0.5,1.0$, and 2.0 times the $50 \%$ inhibitory concentration $\left(\mathrm{IC}_{50}\right)$. The initial velocity was expressed as an increase in absorbance per min. 
activity against $\mathrm{MAO}-\mathrm{A}$ and $\mathrm{MAO}-\mathrm{B}$. The $\mathrm{IC}_{50}$ of compound $\mathbf{1}$ for $\mathrm{MAO}-\mathrm{A}$ was $2.70 \mu \mathrm{M}$, and the selectivity index (SI) was 10.0 versus MAO-B $\left(\mathrm{IC}_{50}\right.$ of compound 1 against $\left.\mathrm{MAO}-\mathrm{B}=27.0 \mu \mathrm{M}\right)$; the $\mathrm{IC}_{50}$ of compound 2 for $\mathrm{MAO}-\mathrm{B}$ was $3.42 \mu \mathrm{M}$, and the SI was low (2.02) versus MAO-A ( $\mathrm{IC}_{50}$ of compound 2 against MAO-A = $\left.6.92 \mu \mathrm{M}\right)($ Table 1$)$. The 1-methylpropyl group in compound 2 had increased MAO-B inhibitory activity compared with the isopropyl group in compound $\mathbf{1}$. Compound $\mathbf{3}$, which had a phenazine instead of a chromenone scaffold, was not effective at inhibiting MAO-A or MAO-B. All three compounds showed little inhibitory activity against AChE, BChE, and BACE-1; the highest $\mathrm{IC}_{50}$ value for compound $\mathbf{1}(31.7 \mu \mathrm{M})$ was against $\mathrm{AChE}$ (Table 1 ). These results indicated that compound $\mathbf{1}$ was a potent and selective inhibitor of MAO-A and that compound $\mathbf{2}$ was a potent and low-selective inhibitor of MAO-B. No tested compounds showed multitargeting inhibitory activities.

Compound 1 in this study was a potent and selective MAO-A inhibitor $\left(\mathrm{IC}_{50}=2.70 \mu \mathrm{M} ; \mathrm{SI}=10.0\right)$, whereas a piloquinone isolated from a marine source in another study was a potent and selective $\mathrm{MAO}-\mathrm{B}$ inhibitor $\left(\mathrm{IC}_{50}=\right.$ $1.21 \mu \mathrm{M} ; \mathrm{SI}=6.47)$ [17]. Compared with other natural inhibitors from microbial sources, compound 1 displayed higher inhibitory activity against MAO-A than did an anithiactin $\left(\mathrm{IC}_{50}=13.0 \mu \mathrm{M}\right)[18], \mathrm{HMC}\left(\mathrm{IC}_{50}=13.97 \mu \mathrm{M}\right)$ [19], and UroA or UroC ( $\mathrm{IC}_{50}=5.88$ or $29.6 \mu \mathrm{M}$, respectively) [32], but it displayed lower inhibitory activity compared with an aplysinopsin $\left(\mathrm{IC}_{50}=0.0056 \mu \mathrm{M}\right)$ [16], UroB $\left(\mathrm{IC}_{50}=0.88 \mu \mathrm{M}\right)$ [32], and an alternariol monomethyl ether $\left(\mathrm{IC}_{50}=1.71 \mu \mathrm{M}\right)$ [33]. Compound 2 was a low-selective $\mathrm{MAO}-\mathrm{B}$ inhibitor $\left(\mathrm{IC}_{50}=3.42 \mu \mathrm{M} ; \mathrm{SI}=\right.$ $2.02)$, and it displayed inhibitory activity against MAO-B similar to that of $\mathrm{HMC}\left(\mathrm{IC}_{50}=3.23 \mu \mathrm{M}\right)[19]$ but lower inhibitory activity than that of a piloquinone $\left(\mathrm{IC}_{50}=1.21 \mu \mathrm{M}\right)[17]$. All three tested compounds had low inhibitory activity against AChE, BChE, and BACE-1.

\section{Reversibilities of Compounds 1 and 2}

In reversibility experiments by dialysis, inhibition of MAO-A by compounds $\mathbf{1}$ and 2 was substantially recovered, from $35.5 \%\left(\mathrm{~A}_{U}\right)$ to $90.9 \%\left(\mathrm{~A}_{\mathrm{D}}\right)$ and from $35.6 \%$ to $79.4 \%$, respectively (Fig. $2 \mathrm{~A}$ ). These values were similar to those observed for the reversible inhibitor toloxatone (33.6\% to $84.2 \%$ ). Little recovery was observed for the irreversible inhibitor clorgyline (36.3\% to 39.7\%) (Fig. 2A). Inhibition of MAO-B by compound 2 was recovered from $34.8 \%\left(A_{U}\right)$ to $76.7 \%\left(A_{D}\right)$, and these recovery values were similar to those observed for the reversible inhibitor lazabemide $(30.5 \%$ to $78.7 \%)$, whereas little recovery was observed for the irreversible inhibitor pargyline (35.4\% to 39.5\%) (Fig. 2B). These results indicated that compound $\mathbf{1}$ was a reversible inhibitor of MAO-A and that compound 2 was a reversible inhibitor of MAO-A and MAO-B.

\section{Kinetics of Compounds 1 and 2}

Modes of MAO-A inhibition by compound $\mathbf{1}$ and modes of MAO-A and MAO-B inhibition by compound 2 were investigated using Lineweaver-Burk plots. Plots of MAO-A inhibition by compound $\mathbf{1}$ were linear and intersected the $y$-axis (Fig. 3A), indicating that compound $\mathbf{1}$ is a competitive inhibitor of MAO-A. Secondary plots of the slopes of the Lineweaver-Burk plots against the inhibitor concentrations showed a Ki value of $0.94 \pm 0.28 \mu \mathrm{M}$ for compound $\mathbf{1}$ (Fig. 3B). Similarly, compound $\mathbf{2}$ was a competitive inhibitor of MAO-A and MAO-B (Figs. 3C and $3 \mathrm{E}$ ); its Ki values were $3.57 \pm 0.60$ and $1.89 \pm 0.014 \mu \mathrm{M}$, respectively (Figs. 3D and 3F).

In this study, three compounds - two chromenones (compounds 1 and 2) and one phenazine (compound 3) were isolated from marine-derived Streptomyces sp. CNQ-031. Compound $\mathbf{1}$ potently and selectively inhibited $\mathrm{MAO}-\mathrm{A}$, and compound 2 inhibited MAO-B and next MAO-A with low selectivity. Compound 3 showed little inhibitory activity against $\mathrm{MAO}-\mathrm{A}$ and $\mathrm{MAO}-\mathrm{B}$. All three compounds weakly inhibited AChE, BChE, and BACE1. Compound $\mathbf{1}$ was a reversible competitive inhibitor of $\mathrm{MAO}-\mathrm{A}$, and compound $\mathbf{2}$ was a reversible competitive inhibitor of MAO-A and MAO-B; thus, both compound $\mathbf{1}$ and compound $\mathbf{2}$ are effective MAO inhibitors from a microbial source.

\section{Acknowledgments}

This study was supported by the National Research Foundation of Korea (NRF) grant No. NRF2019R1A2C1088967, funded by the Korean government of the Republic of Korea.

\section{Conflict of Interest}

The authors have no financial conflicts of interest to declare.

\section{References}

1. Ramsay RR, Albreht A. 2018. Kinetics, mechanism, and inhibition of monoamine oxidase. J. Neural. Transm. 125: 1659-1683.

2. Carradori S, D’Ascenzio M, Chimenti P, Secci D, Bolasco A. 2014. Selective MAO-B inhibitors: a lesson from natural products. Mol. Divers. 18: 216-243.

3. Youdim MB, Edmondson D, Tipton KF. 2006. The therapeutic potential of monoamine oxidase inhibitors. Nat. Rev. Neurosci. 7:295309.

4. Johnston JP. 1968. Some observations upon a new inhibitor of monoamine oxidase in brain tissue. Biochem. Pharmacol. 7: 12851297.

5. Schedin-Weiss S, Inoue M, Hromadkova L, Teranishi Y, Yamamoto NG, Wiehager B, et al. 2017. Monoamine oxidase B is elevated in Alzheimer disease neurons, is associated with $\gamma$-secretase and regulates neuronal amyloid $\beta$-peptide levels. Alzheimers. Res. Ther. 9: 57.

6. Tripathi RKP, Ayyannan SR. 2019. Monoamine oxidase-B inhibitors as potential neurotherapeutic agents: an overview and update. Med. Res. Rev. 39: 1603-1706.

7. Guglielmi P, Carradori S, Ammazzalorso A, Secci D. 2019. Novel approaches to the discovery of selective human monoamine oxidase-B inhibitors: is there room for improvement? Expert Opin. Drug Discov. 14: 995-1035. 
8. Chavarria D, Fernandes C, Silva V, Silva C, Gil-Martins E, Soares P, et al. 2019. Design of novel monoamine oxidase-B inhibitors based on piperine scaffold: structure-activity-toxicity, drug-likeness and efflux transport studies. Eur. J. Med. Chem. 16: 111770.

9. Subaraja M, Vanisree AJ. 2019. The novel phytocomponent asiaticoside-D isolated from Centella asiatica exhibits monoamine oxidase-B inhibiting potential in the rotenone degenerated cerebral ganglions of Lumbricus terrestris. Phytomedicine 58: 152833.

10. Anand P, Singh B. 2013. A review on cholinesterase inhibitors for Alzheimer's disease. Arch. Pharm. Res. 36: 375-399.

11. Kandiah N, Pai MC, Senanarong V, Looi L, Ampil E, Park KW, et al. 2017. Rivastigmine: the advantages of dual inhibition of acetylcholinesterase and butyrylcholinesterase and its role in subcortical vascular dementia and Parkinson's disease dementia. Clin. Interv. Aging 12: 697-707.

12. Ibrahim MM, Gabr MT. 2019. Multitarget therapeutic strategies for Alzheimer's disease. Neural. Regen. Res. 14: 437-440.

13. Ramsay RR, Tipton KF. 2017. Assessment of enzyme inhibition: a review with examples from the development of monoamine oxidase and cholinesterase inhibitory drugs. Molecules 22: E1192.

14. Mathew B, Parambi DGT, Mathew GE, Uddin MS, Inasu ST, Kim H, et al. 2019. Emerging therapeutic potentials of dual-acting MAO and AChE inhibitors in Alzheimer's and Parkinson's diseases. Arch. Pharm. 352: e1900177.

15. Ghosh AK, Osswald HL. 2014. Bace1 (ß-secretase) inhibitors for the treatment of Alzheimer's disease. Chem. Soc. Rev. 43: 1039/ e3cs60460h

16. Baird-Lambert J, Davis PA, Kaylor KM. 1982. Methylaplysinopsin: a natural product of marine origin with effects on serotonergic neurotransmission. Clin. Exp. Pharmacol. Physiol. 9: 203-212.

17. Lee HW, Choi H, Nam SJ, Fenical W, Kim H. 2017. Potent inhibition of monoamine oxidase B by a piloquinone from marine-derived Streptomyces sp. CNQ-027. Int. J. Microbiol. Biotechnol. 27: 785-790.

18. Lee HW, Jung WK, Kim HJ, Jeong YS, Nam SJ, Kang H, et al. 2015. Inhibition of monoamine oxidase by anithiactins from Streptomyces sp. J. Microbiol. Biotechnol. 25: 1425-1428.

19. Jeong GS, Kang MG, Han SZ, Noh JI, Park JE, Nam SJ, et al. 2021. Selective inhibition of human monoamine oxidase B by 5-hydroxy2-methyl-chroman-4-one isolated from an endogenous lichen fungus Daldinia fissa. J. Fungi. 7: 84

20. Hong A, Tu LC, Yang I, Lim KM, Nam SJ. 2020. Marine natural products with monoamine oxidase (MAO) inhibitory activity. Pharm. Biol. 58: 716-720.

21. Baek SC, Park MH, Ryu HW, Lee JP, Kang MG, Park D, et al. 2019. Rhamnocitrin isolated from Prunus padus var. seoulensis: a potent and selective reversible inhibitor of human monoamine oxidase A. Bioorg. Chem. 83: 317-325.

22. Baek SC, Lee HW, Ryu HW, Kang MG, Park D, Kim SH, et al. 2018. Selective inhibition of monoamine oxidase A by hispidol. Bioorg. Med. Chem. Lett. 28: 584-588.

23. Baek SC, Choi B, Nam SJ, Kim H. 2018. Inhibition of monoamine oxidase A and B by demethoxycurcumin and bisdemethoxycurcumin. J. Appl. Biol. Chem. 61: 187-190

24. Baek SC, Ryu HW, Kang MG, Lee H, Park D, Cho ML, et al. 2018. Selective inhibition of monoamine oxidase A by chelerythrine, an isoquinoline alkaloid. Bioorg. Med. Chem. Lett. 28: 2403-2407.

25. Ellman GL, Courtney KD, Andres Jr V, Feather-Stone RM, 1961. A new and rapid colorimetric determination of acetylcholinesterase activity. Biochem. Pharmacol. 7: 88-95.

26. Lee HW, Ryu HW, Kang MG, Park D, Oh SR, Kim H. 2016. Potent selective monoamine oxidase B inhibition by maackiain, a pterocarpan from the roots of Sophora flavescens. Bioorg. Med. Chem. Lett. 26: 4714-4719.

27. Lee JP, Kang MG, Lee JY, Oh JM, Baek SC, Leem HH, Park D, Cho ML, Kim H, 2019. Potent inhibition of acetylcholinesterase by sargachromanol I from Sargassum siliquastrum and by selected natural compounds. Bioorg. Chem. 89: 103043.

28. Jeong GS, Kang MG, Lee JY, Lee SR, Park D, Cho ML, et al. 2020. Inhibition of butyrylcholinesterase and human monoamine oxidase-B by the coumarin glycyrol and liquiritigenin isolated from Glycyrrhiza uralensis. Molecules 25: 3896.

29. Wilson EN, Carmo SD, lulite MF, Hall H, Ducatenzeiler A, Marks AR, et al. 2017. BACE1 inhibition by microdose lithium formulation NP03 rescues memory loss and early stage amyloid neuropathology. Transl. Psychiatry 7: e1190.

30. Qiu D, Zhou M, Lin T, Chen J, Wang G, Huang Y, et al. 2019. Cytotoxic components from hypericum elodeoides targeting RXRa and inducing HeLa cell apoptosis through caspase-8 activation and PARP cleavage. J. Nat. Prod. 82: 1072-1080.

31. Liu H, Zhu G, Zhao S, Fu P, Zhu W. 2019. Bioactive natural products from the marine sponge-derived Nocardiopsis dassonvillei OUCMDZ-4534. Chin. J. Org. Chem. 39: 507-514.

32. Singh R, Chandrashekharappa S, Vemula PK, Haribabu B, Jala VR. 2020. Microbial metabolite urolithin B Inhibits recombinant human monoamine oxidase A enzyme. Metabolites 10: 258 .

33. Lee HW, Kim YJ, Nam SJ, Kim H. 2017. Potent selective inhibition of monoamine oxidase A by alternariol monomethyl ether isolated from Alternaria brassicae. J. Microbiol. Biotechnol. 27: 316-320. 